\title{
The interplay of economic vote dimensions: inequality, redistribution preferences and support for incumbents
}

\author{
Slaven Živković1,2 \\ Accepted: 16 July 2021 / Published online: 21 August 2021 \\ (c) Springer Nature Limited 2021
}

\begin{abstract}
Economic voting is multidimensional (covering valence, patrimony and positional dimensions), and a growing number of research contributions have explored the existence and strength of the effect of these dimensions on voting. However, we know comparatively little about the interplay between these dimensions. This article fills that void by focusing on how the interplay between the rise of income inequality (the valence dimension) and redistribution preferences (the positional dimension) influences support for incumbents. Using the Comparative Study of Electoral Systems (CSES) Modules 4 and 5, I find that preferences for income redistribution reduce the likelihood of voters supporting incumbent parties. Modest evidence demonstrates that this relationship is stronger in countries where inequality increased to a greater degree between elections. Voters who want more redistribution tend to reelect left-wing governments and want to throw out right-wing incumbents. However, rise of inequality hurts both left-wing and right-wing incumbents.
\end{abstract}

Keywords Positional economic voting $\cdot$ Valence $\cdot$ Redistribution $\cdot$ Inequality $\cdot C S E S$

\section{Introduction}

The state of the economy can help us understand voting behavior and explain the election performance of incumbent parties. Scholars have found a strong, positive, consistent effect is produced by the economy on incumbent support (Duch and Stevenson 2008; Lewis-Beck 1988; Lewis-Beck and Stegmaier 2007; Okolikj and Quinlan 2016). Testing the relationship between general economic performance, and voting for incumbents dominates economic voting research.

Slaven Živković

slaven.zivkovic@gesis.org

1 GESIS Leibniz Institute for the Social Sciences, Cologne, Germany

2 Cologne, Germany

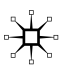


Nevertheless, the premise that citizens, seeing the economy performing poorly, will tend to throw the rascals out, has been contested, as a normatively appealing but theoretically limiting finding (Hellwig 2012). Another important point of valence economic model criticism is partisan contamination bias, meaning that "inferences about the direction of causality between perceptions of the economy and party support remain questionable" (Anderson 2007; Bailey 2019; Evans and Andersen 2006, p. 194). Others have criticized the unidimensionality of economic voting, saying that researchers only focus on valence issues (Lewis-Beck et al. 2013).

In recent years two alternative strands of economic voting research have developed: patrimony and positional economic voting (Lewis-Beck and Nadeau 2011). Patrimony is the dimension that goes beyond perceptions of the economy, and takes into consideration the assets voters hold and how they predict voting behavior (Nadeau et al. 2009). Positional economics assume that voters' positions on economic policy issues shape their vote (Lewis-Beck and Nadeau 2011; Lewis-Beck et al. 2013).

A review of the evolving literature ${ }^{1}$ reveals that researchers have mainly focused on showing that the effect of patrimony and positional economic voting exists and that it is unrelated to valence. Additionally, the positional economics research strand has focused on demonstrating that people who have preferences for leftist (or rightist) policies are more likely to vote for left (or right) parties as a consequence.

However, we know little about the interplay between these dimensions and whether positional economics can influence support for incumbents. Lewis-Beck et al. (2013) showed that patrimony through the positional dimension affects the vote. But what is the role of the interplay between positional economics and valence on vote choice? Are we in danger of overlooking certain connections and findings by treating these dimensions independently, without examining their relationship? Stokes noted that "it is, of course, true that position-issues lurk behind many valence-issues" (1963, p. 373).

This article fills that void by looking at the interplay between valence and positional dynamics and its impact on the vote. For this, I take income inequality (as the valence dimension) and preferences for redistribution (as a positional issue). Dassonneville and Lewis-Beck (2020) show that inequality functions as a valence condition at both the aggregate and the individual level. Preferences for redistribution are an issue that polarizes voters and one where we observe a significant degree of macroheterogeneity (Quinlan and Okolikj 2018). Thus, I take preferences for redistribution as a positional economic issue that is activated, i.e., made more salient by rising inequality.

Apart from disentangling the relationship between the dimensions of the economic vote, studying income inequality is particularly timely, given its rise worldwide (Milanovic 2012). Previous research has shown the adverse consequences

\footnotetext{
1 Some of the notable research contributions are: De Sio and Weber (2014), Hellwig and McAllister (2019), Lewis-Beck and Nadeau (2009), Lewis-Beck and Nadeau (2011), Lewis-Beck et al. (2013), Nadeau et al. (2009), Nezi and Katsanidou (2014), Paparo and Lewis-Beck (2017), Quinlan and Okolikj (2018, 2019), Stubager et al. (2013), Talving (2017).
} 
inequality can have. It can negatively influence the state of democracy (Scheve and Stasavage 2017), economic mobility (Piketty and Saez 2014), political and civic participation (Uslaner and Brown 2005), and even the stability of the economy (Stiglitz 2012). Connecting inequality and redistribution preferences to vote decisions is the growing trend (Pontusson and Rueda 2010; Rueda and Stegmueller 2015). This paper contributes to the ongoing debates on this question by providing a comparative analysis.

To address the research question, I use the Comparative Study of Electoral Surveys (CSES) Module 4 (2018) and Module 5 Advance Release 2 (2020). Analysis reveals that the effect of preferences for redistribution on incumbents' support is stronger in countries with greater (and thus more obvious) increases in income inequality. Furthermore, voters who want more redistribution tend to reelect left-wing incumbents and to replace right-wing ones. Rise of inequality hurts both left-wing and right-wing incumbents.

In the next section, I consider the definition of valence and position issues and then focus on the economy. After that, I proceed to discuss the interplay between valence and positional dynamics and defend my choice of valence issue. Subsequently, I discuss the mechanism through which these are connected with voting for incumbents and devise several hypotheses. Then, I present the relevant data and methods to test these hypotheses, followed by the empirical findings. Finally, I discuss the findings and offer potential new research avenues.

\section{Theoretical framework}

\section{Defining valence and positional issues}

Stokes (1963) defines valence issues as "those that merely involve the linking of the parties with some condition that is positively or negatively valued by the electorate" (p. 373). Positional issues are "those that involve advocacy of government actions from a set of alternatives over which a distribution of voter preferences is defined" (Stokes 1963, p. 373).

However, it is not always easy to distinguish valence issues from positional ones. Two potential sources of confusion are (a) the focus of the policy and (b) the changing nature of the issues.

Fiorina (1981) argues that the distinction between valence and positional issues depends on the focus of the policy, and whether that focus is primarily on means or ends. This dividing line nicely highlights the nature of the issues. For valence issues, people want similar things, such as less terrorism, a good economy, or a good educational system. The means to achieve those ends can be very different. Making a distinction between these issues can be challenging for voters, as this contrast is often not clear even in party manifestos (Curini and Martelli 2015).

On the other hand, the nature of issues can also change. Change can happen over time or between contexts/countries. Divisive issues in one country can be utterly uncontroversial in others. Moreover, voters converge on positional issues, so these 
issues over time change from positional into valence ones (Green 2007). The change in the other direction is also possible.

Stokes (1963) suggested that this matter should be settled empirically. Valence and positional issues have been studied extensively in terms of the economy. The following section provides an overview of both valence and positional economic issues in prominent empirical studies.

\section{The economy as a valence and a positional issue}

In terms of economic voting, valence has been traditionally understood as an evaluation of a country's economic performance. The key assumption is that all citizens want to reap the benefits of a good economy (Tillman 2008). A wealth of literature relies on this assumption and tests whether governments performed well, through the lenses of the state of the economy. ${ }^{2}$ Other valence issues include unemployment (Dassonneville and Lewis-Beck 2013); support for the welfare state (Blomqvist and Green-Pedersen 2004); or bailouts in crisis-affected countries (Magalhães 2012). Recently, Dassoneville and Lewis-Beck (2020) showed that income inequality is a new valence issue, a point to which I will return later.

Issue voting studies have a very long tradition in voting literature (Downs 1957; Rabinowitz and Macdonald 1989). Positional economic voting is an emerging strand of economic voting theory. The economy is becoming an increasingly positional issue, and voters have become more policy-oriented (Lewis-Beck and Costa Lobo 2017). Among the positional economic issues, progressive taxation has been most widely tested in empirical models, both at the national level (Fraile and Lewis-Beck 2013; Lewis-Beck et al. 2013; Lewis-Beck and Nadeau 2011) and comparatively (Paparo and Lewis-Beck 2017). Among other issues, in analyzing the Portugal 2011 election, Costa Lobo (2013) uses four items about the role of the state in the economy. Nezi and Katsanidou (2014) analyze how differences in pro-bailout policies affect voters in Greece, showing that positional economic voting gains strength during times of crisis. Talving (2017) confirms that particular finding utilizing fiscal austerity policies as an economic issue, in a comparative analysis at the European level. One of the most comprehensive tests of positional economic voting comes from Quinlan and Okolikj (2018), who used redistribution, welfare and defense spending as positional issues in their global analysis of the strength of positional economic voting. All of these authors find that positional economics, unrelated to valence, do contribute to explaining vote choice.

However, we know little about the interplay between these two dimensions of the economic vote, as previous research has not tackled these dynamics in detail.

\footnotetext{
${ }^{2}$ Some of the notable contributions and reviews of the literature in the field are: Campbell et al. (1960), Duch and Stevenson (2008), Evans and Andersen (2006), Lewis-Beck (1988), Lewis-Beck and Stegmaier (2018), Lewis-Beck and Stegmaier (2007).
} 


\section{The interplay between valence and positional economy dynamics}

Following Stokes' notion that position issues lurk behind valence ones (1963), I argue that these two strands should be related to each other in studies of economic voting. Valence can be interconnected with positional economics through several mechanisms. The two under consideration here are that: (a) Valence issues can make citizens prefer one policy option over other(s); and (b) valence can increase the salience of the position issues. To demonstrate these processes, let us turn our attention to the empirical world.

Income inequality is correlated with preferences for redistribution. Voluminous literature on political economy has shown that inequality has a significant effect on actual levels of redistribution (McCarty and Pontusson 2011) as well as support for redistribution (Alt and Iversen 2017). Traditional models of political economy state that preferences for redistribution depend on an individual's income. The seminal work in the field provides the most simplistic version of this logic. In it, Meltzer and Richard (1981) claimed that all individuals who have an above-median income in society want less redistribution, and those who have an income lower than the median want more. Their model implies that there will be more redistribution in unequal societies, because a low median income relative to the society's income mean is a sign of significant inequality (Lind 2005).

The more inequality there is, the more salient the topic of inequality and redistribution becomes (Milanovic and Roemer 2016), and saliency exerts a particular effect on policy responsiveness (Franklin and Wlezien 1997). Lax and Phillips showed that when an issue is not salient it is hard to expect that it will turn into policy (2009). As argued above, income inequality became more salient over time. Here, I argue that rise of income inequality has become a valence issue, which I defend in the following section.

\section{Rise of income inequality as a valence issue}

This section aims to provide evidence that inequality should be treated as a valence issue. Backing for that view lies in (a) previous research findings; (b) citizens' prevailing view that differences in income are too large; and (c) the attitudes of different groups toward income inequality.

First, Dassonneville and Lewis-Beck (2020) find that across time and space, on a sample of 318 elections in 37 countries from 1963 up to 2017, support for incumbents is influenced by economic growth (positive effect) as well as income inequality (negative effect). Furthermore, they find that both left- and right-wing incumbents are held accountable and have worse electoral results when the inequality is on the rise. From this compelling evidence, they conclude that income inequality does not function as a positional issue, but rather as a valence one.

Secondly, the majority of citizens think that differences in income are too large in their country. On a sample of 41 countries that participated in the International Social Survey Programme (ISSP) module on Social Inequality from 


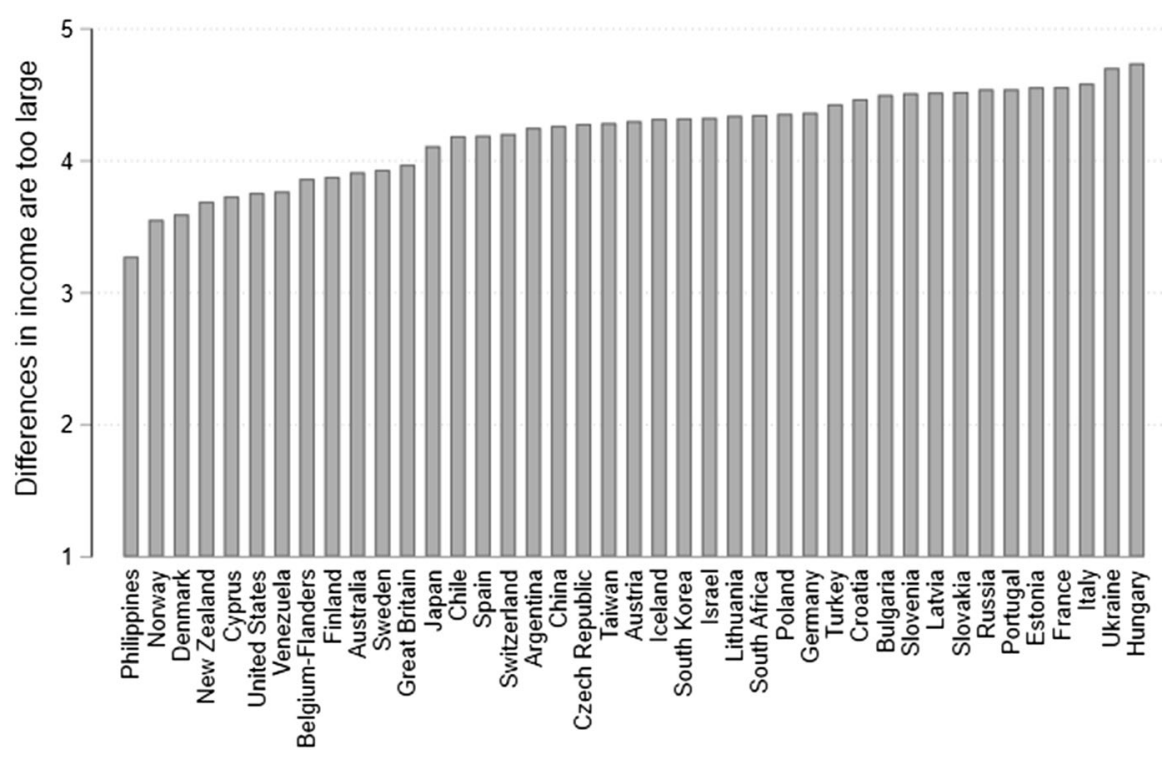

Fig. 1 Differences in income are too large, mean by country. Source: Ganzeboom 2015

2009, we can see some country variation on the issue. However, in all countries, above $50 \%$ of the population agree/strongly agree that differences in income are too large in their country (ISSP 2019). Further, on a total sample, a very high percentage, $83.5 \%$, of respondents share this view. While historically, some countries were known and strong advocates of market-oriented policies which generated higher inequality (USA or UK, to name a few), this seems to be slowly changing for some of them. It would not be a first time, nor a first issues which converted from positional to valence. The graph shows the mean value per country on a 5-point scale and illustrates the previous point (Fig. 1).

Finally, inequality affects citizens from all walks of life. Poor people and the middle class are affected because inequality reduces economic mobility. But richer groups in society are also negatively influenced by the rising income inequality. Namely, Rehm et al. (2012) showed that inequality presents a considerable risk for wealthier citizens too, as economic disadvantage (a key problem of low-income people) and economic insecurity (a significant risk for people with higher incomes) are correlated. Furthermore, Rueda and Stegmueller (2016), analyzing the USA, found that affluent individuals are more supportive of redistribution in states with greater inequality.

I argue that inequality should be treated as a valence issue, but the policies intended to deal with it are positional. In the following section, I develop a model combining inequality, preferences regarding redistribution, and support for incumbents. 
Fig. 2 Hypothesis 1

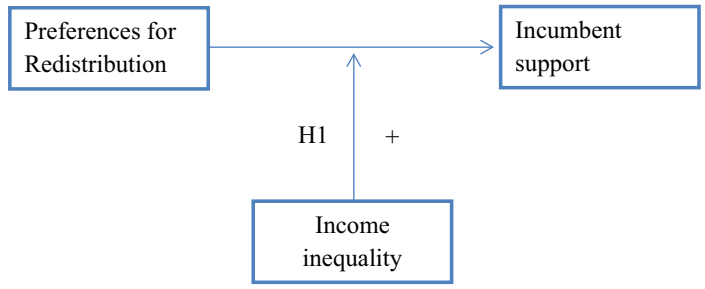

\section{Inequality, redistribution and support for incumbents}

This section develops a model showing how inequality and redistribution, affecting one another, has the ability to predict vote for incumbents. Here I build on the previous sections and connect the three concepts into a single model.

Extensive literature, with a good proportion of it coming from economic voting studies, clearly shows that valence as an element influences political attitudes and voting (Clarke et al. 2015; Lewis-Beck et al. 2013; Lewis-Beck and Stegmaier 2000). These are issues where parties want to convince voters of their competence (Tillman 2008). Or, as Clarke et al. put it, "in the realm of valence politics, it is not 'what', but rather 'who', and 'how' that matters" (2011, p. 238).

The "who" part of the quote refers to-which party? However, I focus on incumbency, because governments are the actors that are held responsible for adopting and implementing policies (Leon 2011). Thus, I expect incumbents to be rewarded (or alternatively punished) for the policies they (fail to) implement.

When voters differ on the means (the "how") used to achieve a set goal, they differ on policies. Political economy literature shows that the greater the level of inequality is, the more redistribution people want (Lind 2005). Following this, I assume that voters hold governments accountable for fighting inequality and for implementing redistributive policies (Iversen 2011; Lind 2005). Thus, the effect of redistribution preferences should be reflected in government support, and because inequality makes redistribution more salient, I expect the impact of redistribution preferences on incumbent support to be stronger, where income inequality is greater (H1). (Fig. 2).

Not all governments will be evaluated in the same way by voters. Typically left (or right) leaning voters expect the parties they vote for to provide left (right) policies. If they fail to do so, there is often a perception that they should be punished. Here, the mixture of traditional incumbency-oriented economic voting with the partisan theory of economic voting comes into play. Powell and Whitten found evidence that voters actually hold governments to different standards depending on their own ideological preferences (1993).

The cleavage between left and right is easy to recognize in the economy, as most are aware of what the relevant position issues are concerning the economy advocated by the left and by right-wing parties, respectively (Dassonneville and Lewis-Beck 2013). Redistribution is one of those issues, "the core issue of contention between parties of the Left and Right" (Pontusson and Rueda 2010, p. 674). 
Fig. 3 Hypothesis 2

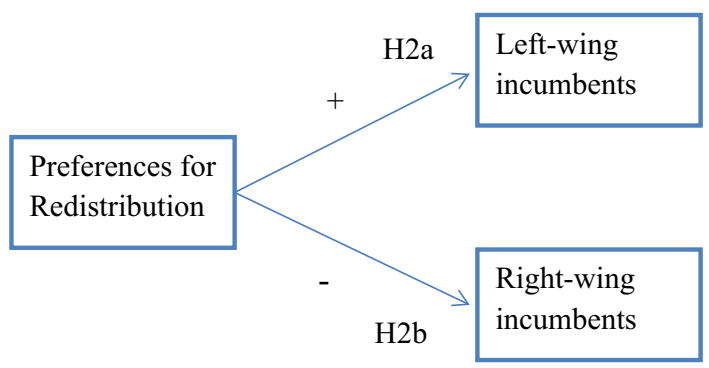

Fig. 4 Hypothesis 3

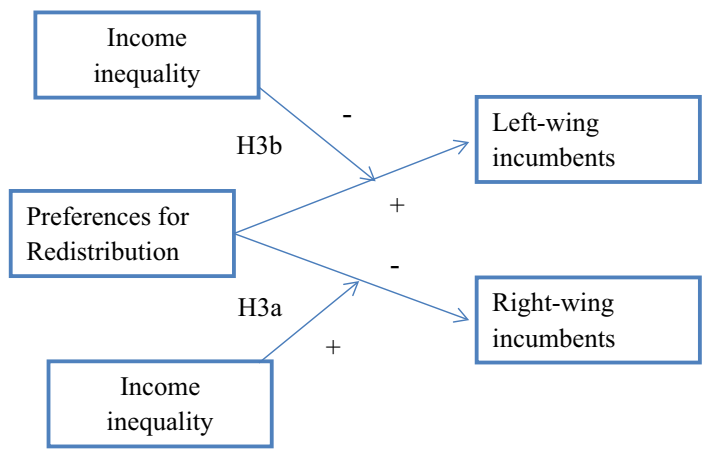

From the extant positional economic voting literature, we know that the different ideological orientations of incumbents mediate the role of citizens' position on specific economic issues. Thus, I expect that voters who want more redistribution will reward and re-elect left-wing incumbents $(\mathrm{H} 2 \mathrm{a})$ and will punish and throw out rightwing governments (H2b) (Fig. 3).

The remaining question is what kind of influence the change in inequality produces in terms of these links?

For right-wing incumbents, the answer seems to be straight-forward. We should expect that (a) people who want more redistribution will tend to punish and replace right-wing incumbents; and (b) that rising inequality will make the impact of preferences for redistribution on vote choice stronger. Hence, I assume that the negative effect of preferences for redistribution on right-wing incumbents will be stronger in countries with a greater rise in income inequality (H3a).

On the other hand, left-wing incumbents are expected to gain support from those who favor redistributive policies. The question then arises as to what kind of effect rising inequality will actually have. Dassoneville and Lewis-Beck (2013) showed that left-wing governments are more severely punished in periods of rising unemployment, meaning that the role of positional economics is dependent on valence. Left-wing parties are typically seen as the owners of this issue and the parties most capable of tackling problems related to levels of unemployment. The same argument can be made for redistribution. Thus, my assumption is that left-wing incumbents will be punished by voters who want more redistribution when inequality is on the rise (H3b) (Fig. 4). 


\section{Data and methods}

To test the above set assumptions, I use the Comparative Study of Electoral Systems (CSES) Module 4 Full Release (2018) and Module 5 Advance Release 2 (2020). First, I subset the data to all available democracies in the dataset (based on Freedom House Rating, all countries that score 2.5 or lower or a Freedom House scale), since in non-democratic regimes, incumbents tend to perform better than economic conditions warrant. Second, I exclude studies for which data are missing on some crucial variables or for which there are substantive reasons for excluding them. ${ }^{3}$ After that, I am left with the 42 studies from 33 countries. ${ }^{4}$ Due to unit non-response, there are 35,864 respondents in the main models.

Since I am testing the interplay of economic vote dimensions and the role positional dimension (taking stances on positional economic issues) have on governments' electoral fortunes, I take the same approach as the vast majority of economic voting research, which tests the reward-punishment mechanism. Thus, the dependent variable is support for incumbents, coded 1-voted for the outgoing government; 0 - other. This goes in line with previous findings, as literature shows that voters perceive electoral contention in terms of winners and losers and more concretely in or out of the governing role (Anderson et al. 2005; Stiers et al. 2018). Further, Stiers et al. (2018) find evidence that voters perceive the party that won the most votes as clear election winners. These parties, though not always, tend to be the ones that hold the position of Prime minister. Thus, as part of the robustness checks, I also run the same models, with dependent variable coded 1 -voted for the party of the Prime minister; 0-other, to account for the effects of inclusion/exclusion of minor coalition partners. Results do not change much with different specification of the dependent variable. ${ }^{5}$

\footnotetext{
${ }^{3}$ The following election studies are dropped from the analysis:
}

- From CSES Module 4: Greece (2012) because the government at the time of election was caretaker, and all its members were independents; Latvia (2011) as data on redistribution preferences are missing for that study; Romania (2014) because study relates to presidential election, and incumbents could not be ascertained and linked to the party, since President Basescu technically ran on a Democrat Liberal Party (PDL) ticket in 2009, but Romanian presidents cannot be legally a member of a party and Basescu was also closer to the People's Movement Party (PMP); Peru (2016) as incumbents did not field the candidate for the 2016 elections; Taiwan (2012) because left-right is not relevant in Taiwan (Jou 2010); Switzerland (2011) due to the consociational nature of their government, making it impossible to distinguish between incumbents and opposition. Thus, due to the consociational system, the expectation is that the reward-punishment mechanism will not operate in conventional fashion; and South Korea (2012) because of the missing data on several explanatory variables used in the model.

- From CSES Module 5: Greece (2015) and Ireland (2016) because these two studies were fielded as pre-test and have different redistribution items in the study, thus missing data for the key explanatory variable; and Australia (2019) and two Iceland (2016, 2017) studies because of the missing data on several explanatory variables used in the model.

4 See Appendix 2 for more details on the election studies included, year of election, party of prime minister, coding of incumbent parties, and MARPOR/CSES classification of left-right incumbents.

5 For full models with different dependent variable specification (vote for the party of prime minister) please see Appendix 4. 
For redistribution preferences, I take the typical survey item, whether respondents agree with the statement, "the government should take measures to reduce differences in income levels." The variable responses range on a 5-point scale from "strongly disagree" to "strongly agree."

Assessment of the economy over the previous twelve months prior to the elections is also included as part of the model. Respondents evaluated the economy using the 5-point scale, ranging from "the economy is much worse than it was 12 months ago" to "the economy is significantly better than it was 12 months ago."

To address "concerns that partisan and/or ideological bias may pollute economic positions and perceptions" (Quinlan and Okolikj 2018), I include ideology and party identification as part of the model. For ideology, I take respondents' self-placement on an ideological scale from 0 (left) to 10 (right). The variable is first multiplied by -1 (then +1 added) if the government is left-wing (Nadeau et al. 2013). Party identification is coded as binary, with 1 representing respondents' identification with the incumbent party; 0 others.

The usual suspects, socio-demographic variables, also form part of the model: gender, age (mean-centered), education and income. A dummy indicator for union membership is added, given the interconnection between membership of unions and voting for left-wing parties, as well as redistribution preferences.

In relation to context, I use the change in inequality (GINI), the difference between the level of inequality in an election year and the level in the year of the previous election. There are three reasons for taking this measure, rather than just the simple level of inequality. First, I argue that it is not inequality itself that is problematic, but rather the rise of inequality. The second and third reasons explain the way the variable is constructed. I take changes of inequality between two elections to account for the rise/decrease of inequality levels in the whole governments' term, even though these terms are not always of the same duration. Finally, inequality is something that changes slowly over time. Taking only the most recent years into account (i.e., the election year and the year immediately before) would give us a variable with minimal variation. Thus, I take the change in the period between the two elections. During that period, two-thirds of the countries in the analysis witnessed a rise in inequality (Fig. 5).

To tackle the traditional economic macro-indicators and in an attempt to disentangle the rise in inequality from other economic problems, I control for-GDP growth (annual) and the change in unemployment (for the election year minus the year before). This approach avoids the problem of collinearity (Nedau et al. 2013). ${ }^{6}$

A dummy indicator for left-wing governments is included. The distinction between left-wing and right-wing governments is based on the ideology of the party of the Prime minister. Hellwig showed that "voters assign most, if not all, credit or blame for economic performance to this party, even in cases of coalition governments" (2012). Parties are classified on a left-right scale using MARPOR data ${ }^{7}$ (2020). Additionally, instead of dummy classification, I have used MARPOR's rile

\footnotetext{
${ }^{6}$ Data come from the World Bank.

7 Appendix 2 lists incumbent parties, as well as the MARPOR/CSES classification.
} 


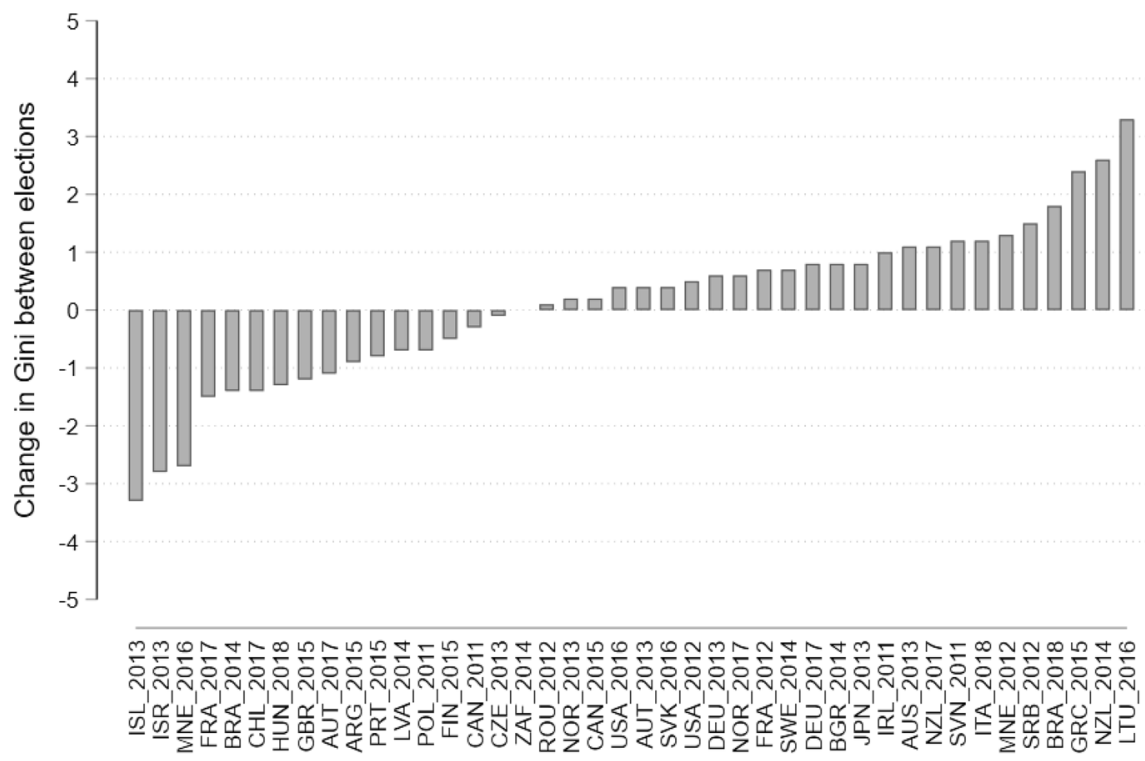

Fig. 5 Change in inequality between elections

score (2020) for a party of Prime minister, to classify countries in the analysis, as a robustness check. I take this approach, acknowledging that binary classification potentially hides party differences within these two broad groups. Effect for the interaction between redistribution preferences and MARPOR's rile scale remains in the expected direction and statistically positive. Results are presented in Appendix 5.

Because of the structure of the dataset, to avoid the violation of the independence of observations, and due to the binary dependent variable, I fit a multilevel logit model, ${ }^{8}$ with several interactions to test the effect of redistribution preferences and levels of inequality changes, and redistribution preferences and indicator for leftwing incumbents. I add random slope for redistribution preferences, as lower-level variable in the interaction, following Heisig and Schaeffer (2019).

\section{Analysis}

First, it is worth mentioning that the empirical models provide evidence in support of a long-lasting incumbency-oriented hypothesis about the relationship between the perception of the economy and support for incumbents. Respondents who

\footnotetext{
${ }^{8}$ Fitting a baseline model with a varying intercept on a dummy variable, showed ICC was 0.18 , meaning that, aside from theoretical issues, there were also statistical reasons to model the vote using multilevel logistic regression.
} 
Table 1 Multi-level logistic regression models — vote for incumbents

\begin{tabular}{|c|c|c|c|c|}
\hline Vote for incumbents & Model 1 & Model 2 & Model 3 & Model 4 \\
\hline Redistribution preferences & $\begin{array}{l}-0.571 * * * \\
(0.164)\end{array}$ & $\begin{array}{l}0.242 \\
(0.418)\end{array}$ & $\begin{array}{l}-0.974 * * * \\
(0.188)\end{array}$ & $\begin{array}{l}-0.113 \\
(0.425)\end{array}$ \\
\hline State of economy & $\begin{array}{l}1.436^{* * *} \\
(0.0639)\end{array}$ & $\begin{array}{l}1.432 * * * \\
(0.0639)\end{array}$ & $\begin{array}{l}1.432 * * * \\
(0.0636)\end{array}$ & $\begin{array}{l}1.426^{* * * *} \\
(0.0637)\end{array}$ \\
\hline Party ID & $\begin{array}{l}3.113 * * * \\
(0.0441)\end{array}$ & $\begin{array}{l}3.111^{* * * *} \\
(0.0441)\end{array}$ & $\begin{array}{l}3.109 * * * \\
(0.0441)\end{array}$ & $\begin{array}{l}3.108^{* * * *} \\
(0.0441)\end{array}$ \\
\hline Ideology & $\begin{array}{l}1.524 * * * \\
(0.0609)\end{array}$ & $\begin{array}{l}1.528^{* * * *} \\
(0.0609)\end{array}$ & $\begin{array}{l}1.516^{* * *} \\
(0.0606)\end{array}$ & $\begin{array}{l}1.523^{* * * *} \\
(0.0608)\end{array}$ \\
\hline Income & $\begin{array}{l}-0.0992 * \\
(0.0444)\end{array}$ & $\begin{array}{l}-0.0997^{*} \\
(0.0444)\end{array}$ & $\begin{array}{l}-0.0920^{*} \\
(0.0444)\end{array}$ & $\begin{array}{l}-0.0927 * \\
(0.0444)\end{array}$ \\
\hline Union membership & $\begin{array}{l}-0.00102 \\
(0.0393)\end{array}$ & $\begin{array}{l}-0.000316 \\
(0.0393)\end{array}$ & $\begin{array}{l}-0.00528 \\
(0.0393)\end{array}$ & $\begin{array}{l}-0.00465 \\
(0.0392)\end{array}$ \\
\hline Male & $\begin{array}{l}-0.209 * * * \\
(0.0281)\end{array}$ & $\begin{array}{l}-0.209^{* * *} \\
(0.0281)\end{array}$ & $\begin{array}{l}-0.209^{* * *} \\
(0.0281)\end{array}$ & $\begin{array}{l}-0.209^{* * *} \\
(0.0281)\end{array}$ \\
\hline Age & $\begin{array}{l}-0.00405^{* * *} \\
(0.000883)\end{array}$ & $\begin{array}{l}-0.00391^{* * *} \\
(0.000880)\end{array}$ & $\begin{array}{l}-0.00374 * * * \\
(0.000871)\end{array}$ & $\begin{array}{l}-0.00363^{* * *} \\
(0.000875)\end{array}$ \\
\hline Education & $\begin{array}{l}-0.186^{* * *} \\
(0.0455)\end{array}$ & $\begin{array}{l}-0.192 * * * \\
(0.0456)\end{array}$ & $\begin{array}{l}-0.201 * * * \\
(0.0453)\end{array}$ & $\begin{array}{l}-0.206^{* * *} \\
(0.0454)\end{array}$ \\
\hline$\Delta$ Gini & $\begin{array}{l}-0.318 \\
(0.699)\end{array}$ & $\begin{array}{l}0.631 \\
(0.699)\end{array}$ & $\begin{array}{l}-1.304 * * * \\
(0.288)\end{array}$ & $\begin{array}{l}-0.252 \\
(0.604)\end{array}$ \\
\hline Left government & $\begin{array}{l}-0.506 \\
(0.274)\end{array}$ & $\begin{array}{l}-0.502 \\
(0.261)\end{array}$ & $\begin{array}{l}-1.029 * * * \\
(0.251)\end{array}$ & $\begin{array}{l}-0.970^{* * * *} \\
(0.247)\end{array}$ \\
\hline GDP growth & $\begin{array}{l}1.045 \\
(0.782)\end{array}$ & $\begin{array}{l}0.973 \\
(0.722)\end{array}$ & $\begin{array}{l}-0.427 \\
(0.322)\end{array}$ & $\begin{array}{l}-0.219 \\
(0.339)\end{array}$ \\
\hline$\Delta$ Unemployment & $\begin{array}{l}0.139 \\
(0.686)\end{array}$ & $\begin{array}{l}0.159 \\
(0.671)\end{array}$ & $\begin{array}{l}1.344 * * * \\
(0.381)\end{array}$ & $\begin{array}{l}1.075^{*} \\
(0.525)\end{array}$ \\
\hline Redistribution $\times \Delta$ Gini & & $\begin{array}{l}-1.545^{*} \\
(0.724)\end{array}$ & & $\begin{array}{l}-1.538^{*} \\
(0.694)\end{array}$ \\
\hline Redistribution $\times$ Left gov & & & $\begin{array}{l}1.303 * * * \\
(0.270)\end{array}$ & $\begin{array}{l}1.123^{* * * *} \\
(0.277)\end{array}$ \\
\hline Constant & $\begin{array}{l}-2.096^{* *} \\
(0.736)\end{array}$ & $\begin{array}{l}-2.524 * * * \\
(0.650)\end{array}$ & $\begin{array}{l}-0.963^{* * *} \\
(0.233)\end{array}$ & $\begin{array}{l}-1.499 * * * \\
(0.448)\end{array}$ \\
\hline \multicolumn{5}{|l|}{ Random effects and slopes } \\
\hline Redistribution preferences & $\begin{array}{l}1.244 * * * \\
(0.283)\end{array}$ & $\begin{array}{l}1.161 * * * \\
(0.255)\end{array}$ & $\begin{array}{l}1.006^{* * *} \\
(0.245)\end{array}$ & $\begin{array}{l}0.963 * * * \\
(0.234)\end{array}$ \\
\hline Election study & $\begin{array}{l}0.863 * * * \\
(0.201)\end{array}$ & $\begin{array}{l}0.830^{* * * *} \\
(0.184)\end{array}$ & $\begin{array}{l}0.902 * * * \\
(0.191)\end{array}$ & $\begin{array}{l}0.804^{* * * *} \\
(0.181)\end{array}$ \\
\hline$A I C$ & $32,291.2$ & $32,279.9$ & $32,245.8$ & $32,251.5$ \\
\hline$B I C$ & $32,427.0$ & $32,424.1$ & $32,390.1$ & $32,404.2$ \\
\hline $\mathrm{Ll}$ & $-16,129.6$ & $-16,122.9$ & $-16,105.9$ & $-16,107.7$ \\
\hline M \& Z-Pseudo R2 & 0.5282 & 0.5285 & 0.5277 & 0.5276 \\
\hline Observations & 35,864 & 35,864 & 35,864 & 35,864 \\
\hline Number of election studies & 42 & 42 & 42 & 42 \\
\hline
\end{tabular}


Table 1 (continued)

Standard errors in parentheses; $* p<0.05$, ** $p<0.01$, *** $p<0.001$; Source: CSES Module 4 (2018) \& CSES Module 5 (2020)

considered the economy to be better than it was year ago, were more likely to vote for incumbents (Table 1).

The main independent variable in the model, redistribution preferences, is connected with support for incumbents. The more a voter wants redistribution, the less likely they are to support incumbents. To further explore the relationship between redistribution preferences and incumbents support, and to make better sense of the logit coefficient, I have calculated the expected change in incumbents' vote share if preferences for redistribution were to change by one standard deviation. Since the distribution of the dichotomous dependent variable is $0.6(0)$ and $0.4(1)$, I used a linear probability estimate with OLS to calculate the vote share by multiplying the regression coefficient by the variable mean absolute deviation (Lewis-Beck and Quinlan 2019). With an increase in redistribution preferences of one standard deviation, incumbent vote share is expected to decrease by $6.4 \%$.

The effect of the interaction between redistribution preferences and the change in Gini is in the expected direction. Voters who prefer more redistribution tend to punish governments more in countries that experience a greater rise in inequality. The effect provides evidence for H1. Additionally, the coefficient for preferences for redistribution in Model 2, after including the interaction, is positive and significant. This coefficient (Brambor et al. 2006) indicates that voters who want more redistribution are more likely to reelect incumbents in countries which have low scores on the variable changes of inequality (so the countries where inequality levels reduced or stayed the same in-between election years).

For the substantive effect, I follow Williams (2012) and examine the marginal effect of the variable of interest at representative values of the other variable. Thus, I plot the effect of redistribution preferences over the change in inequality.

Figure 6 reveals weak substantive evidence for H1. The marginal effect of redistribution preferences slightly changes with a rise in inequality, but the change of the interaction effect is in the expected direction. However, the effects are small and the confidence intervals large, thus there is not insufficient evidence to substantiate H1.

Model 3 shows that voters who want more redistribution, in a country with leftwing incumbents, are more likely to reelect them $(\mathrm{H} 2 \mathrm{a})$, and voters wanting more redistribution in countries with right-wing incumbents are more likely to support the opposition $(\mathrm{H} 2 \mathrm{~b})$. To allow readers to more intuitively grasp the meaning behind this interaction, I have recalculated the same model (Model 3), with the rescaled variable ${ }^{9}$ included in the interaction, so that it is easier to present the marginal effects at the two levels of the left-wing government dummy (Williams 2012) (Fig. 7).

\footnotetext{
9 Preferences for redistribution have been rescaled to three-category variable merging categories somewhat and strongly disagree into one, and somewhat/strongly agree into another category. "Neither agree nor disagree" remains the middle category.
} 


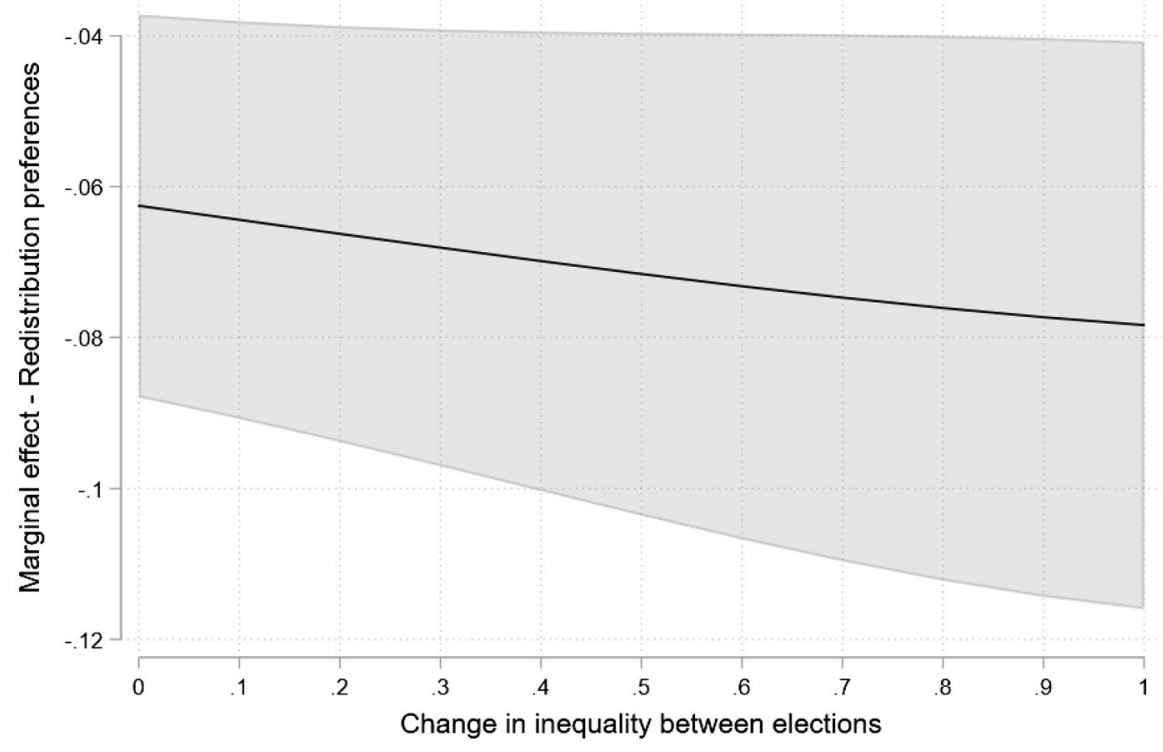

Fig. 6 Average marginal effect of redistribution over the change of inequality with a 95\% CI

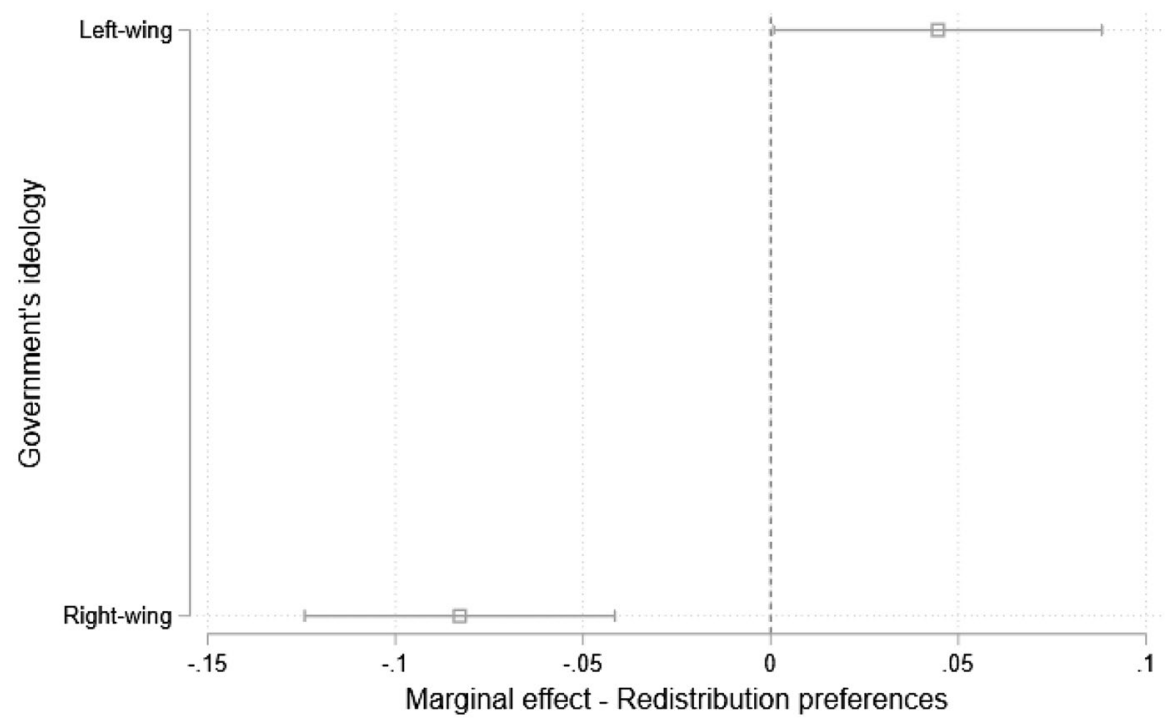

Fig. 7 Marginal effect of preferences for redistribution over the government's ideology with a 95\% CI

The graph shows that voters align with what parties usually stand for. Those who want more redistribution tend to vote for left-wing governments and punish the right-wing ones. 

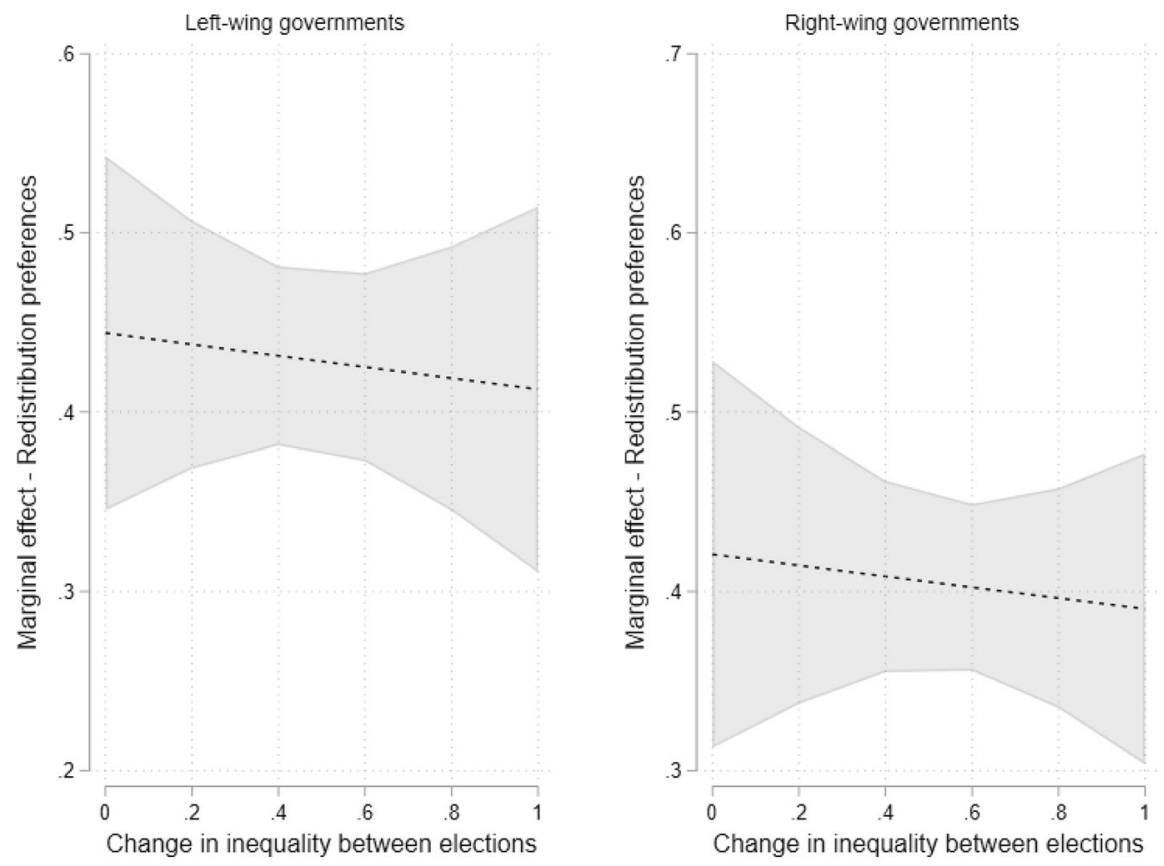

Fig. 8 Marginal effect of preferences for redistribution over the change of inequality with a 95\% CI, for left-wing and right-wing governments

For $\mathrm{H} 3 \mathrm{a}$ and $\mathrm{H} 3 \mathrm{~b}$, I present marginal effect of redistribution preferences (for respondents who want more redistribution on the same, above-mentioned, three-category redistribution variable) over different values of inequality changes in between elections, separately for left-wing incumbents and right-wing incumbents. The results are in the following figure (Fig. 8).

As we can see from both the models and the plotted effects, there is modest support for $\mathrm{H} 3 \mathrm{a}$ and $\mathrm{H} 3 \mathrm{~b}$. Both left-wing and right-wing incumbents are punished by voters who want more redistribution in countries that have experienced a rise in income inequality. However, the effects are not that pronounced.

I conclude by summarizing and discussing these findings and their implications.

\section{Discussion}

The economy is still a strong predictor of vote choice. The effect of the evaluation of the economy is one of the strongest predictors of the level of vote for incumbents across the countries in the analysis. Is there anything left for economic issues in this equation? Positional economic voting research, we might argue, is sometimes trapped into showing the tautological relationship between the variables and the ideological leanings of political parties. I take a different approach, trying to show how 
taking a position on economic issues affects performance evaluation conditional on the incumbents' ideology.

Voters care about redistribution; models provide evidence that preferences for redistribution influence both vote choice and support for incumbents. Additionally, I find very modest support that the effect of preferences for redistribution is stronger in countries where inequality increased more significantly between elections. Further disentangling this relationship with vote could provide more robust findings. This modest finding for $\mathrm{H} 1$ in this paper, and potentially similar more robust findings in the future, could be expected and explained by the fact that in the period after the Global Financial Crisis, inequality increased worldwide, which made redistribution more salient as an issue.

The effect of redistribution interacting with an indicator for left-wing governments showed that voters cast their votes in accordance with the longstanding positions of the parties and vote for those who are close to their ideological position (Ferland and Dassonneville 2019). "In general, the 'partisan theory' of political competition assumes that left-wing parties represent lower-income voters and right-wing parties, high-income voters. Hence, if a leftist government is in power, it should opt for higher spending on items which redistribute to the poor" (Borck 2007). Borck's explanation seems to capture the essence of the effect-those who want more redistribution, tend to keep left-wing incumbents and remove right-wing ones. In this case, voters opt not to sanction, but to choose based on competency (Hellwig 2012).

Further exploring the role of inequality in the relationship between preferences for redistribution and vote for left-wing and right-wing incumbents highlighted the fact that voters who want more redistribution punish both types of incumbent when income inequality is on the rise. However, the effect, across different levels of increases in inequality, is slightly more pronounced for left-wing governments. The strength of these effects is modest.

The analysis provides very modest support (at best) for the view that changes in inequality negatively influence support for incumbents. It seems that inequality influences attitudes (such as preferences for redistribution), which further affect incumbent support. Scholars trying to tie inequality to government support should be aware of two further issues: (a) The relationship should be tested against the change in inequality, rather than actual levels of inequality; and (b) the period for capturing the change in inequality should be longer, not just focused on the change in the previous year.

Unfortunately, the data do not provide us with the measure of perceived inequality, nor any indication of how much blame citizens place on government for rising inequality. Who citizens actually blame for rising inequality would be an interesting research question but is not in the scope of this article. Here, I make the argument that inequality indirectly affects incumbents through preferences for redistribution.

Future research on the topic should consider panel data (when possible) in an attempt to better understand the dynamics of changes in both inequality and redistribution preferences over time. Potential fertile ground for the next step in this direction would be to include, not just income inequality, but also wealth inequality, since research shows that wealth inequality is even more pronounced than 
income inequality (Alvaredo et al. 2017). Researchers could explore the mechanisms between vote choice and wealth inequality and the policies that combat wealth inequality. Further, talking about the theoretical foundations of this paper, future research should explore the role of patrimony, the third dimension of economic vote, as Lewis-Beck et al. (2013) scratched the surface of that topic.

Lastly, this research could be an added argument in the very heated discussion about the "crises of the left," especially in Europe and the future of left-wing parties more generally, since it shows that they are still winning on one of their traditional stronghold issues-preferences for redistribution.

\section{Appendix}

\section{Appendix 1}

See Fig. 9.

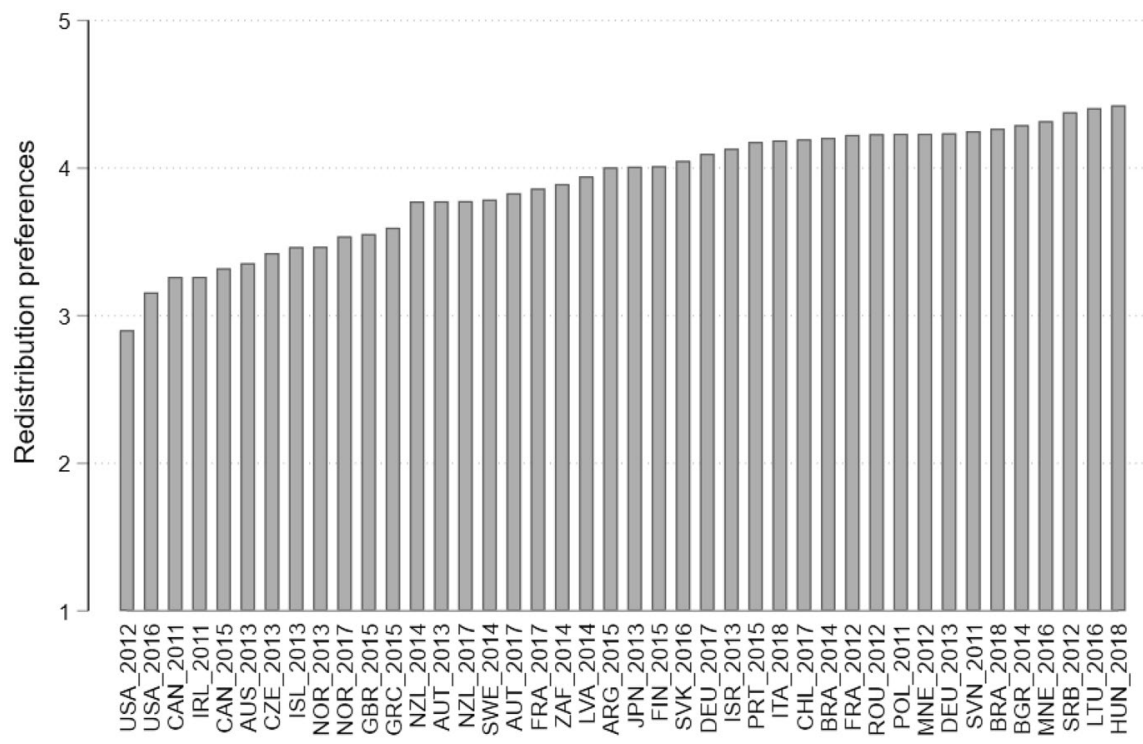

Fig. 9 Redistribution preferences across election studies in the sample

\section{Appendix 2}

See Table 2. 


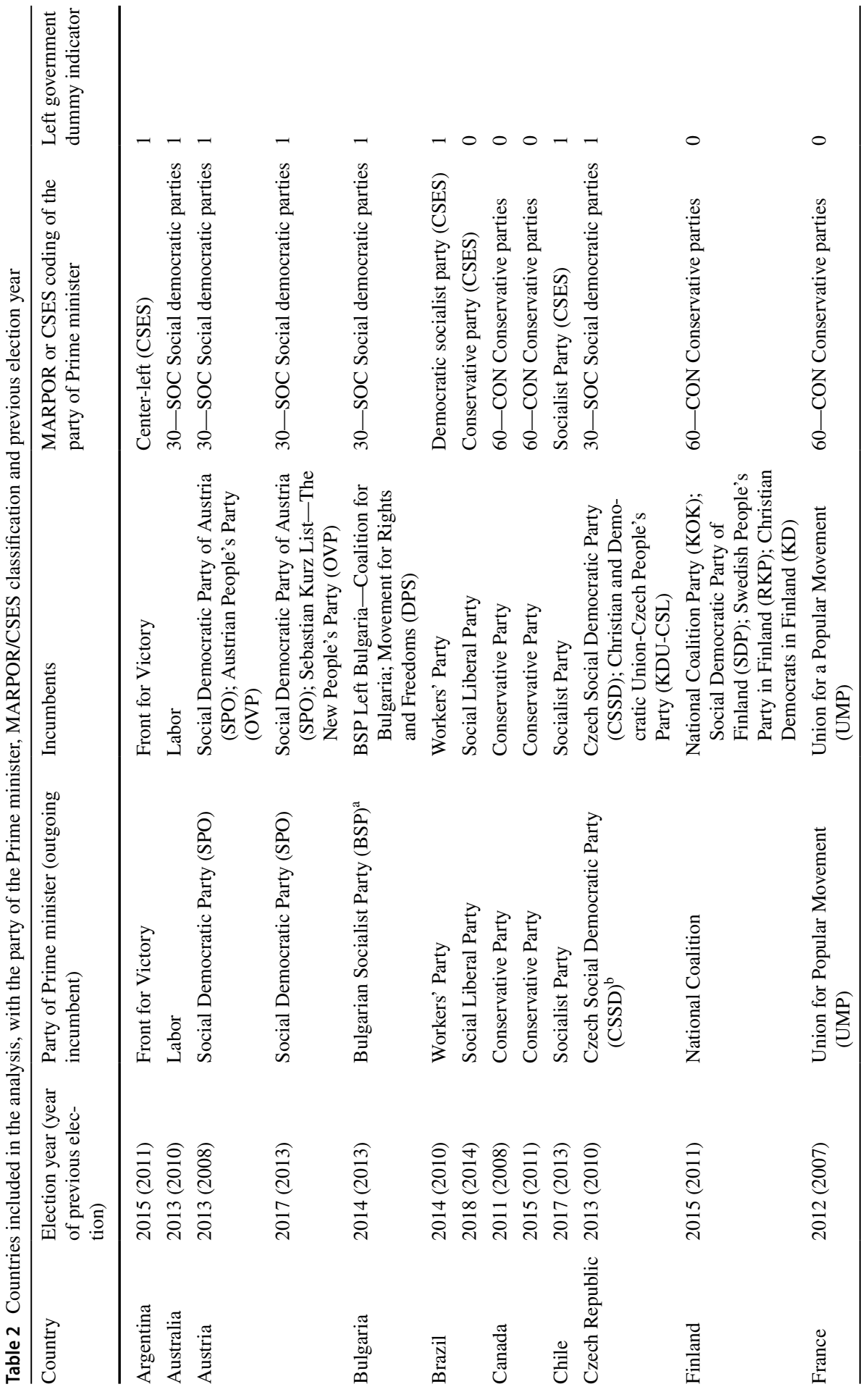




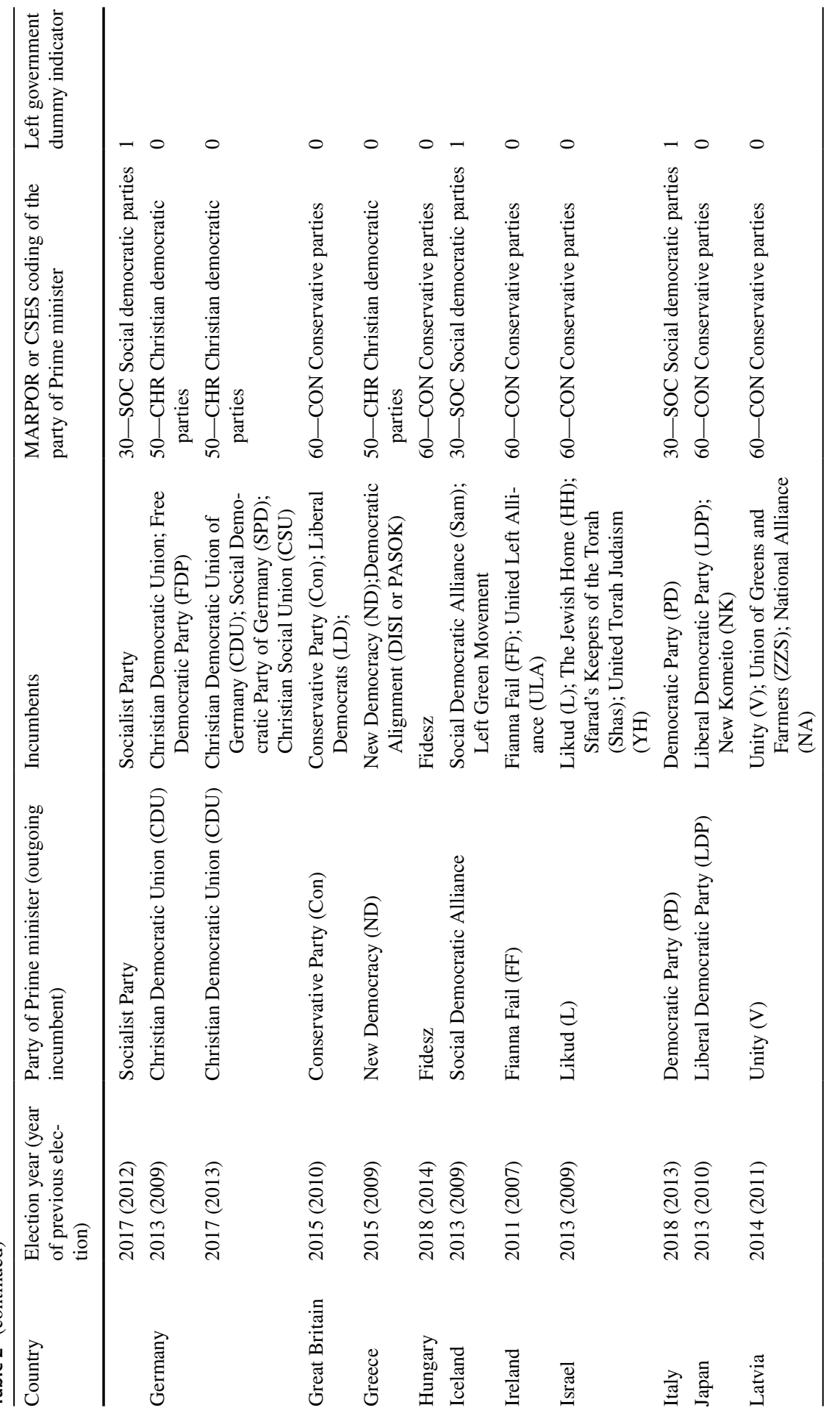

称 


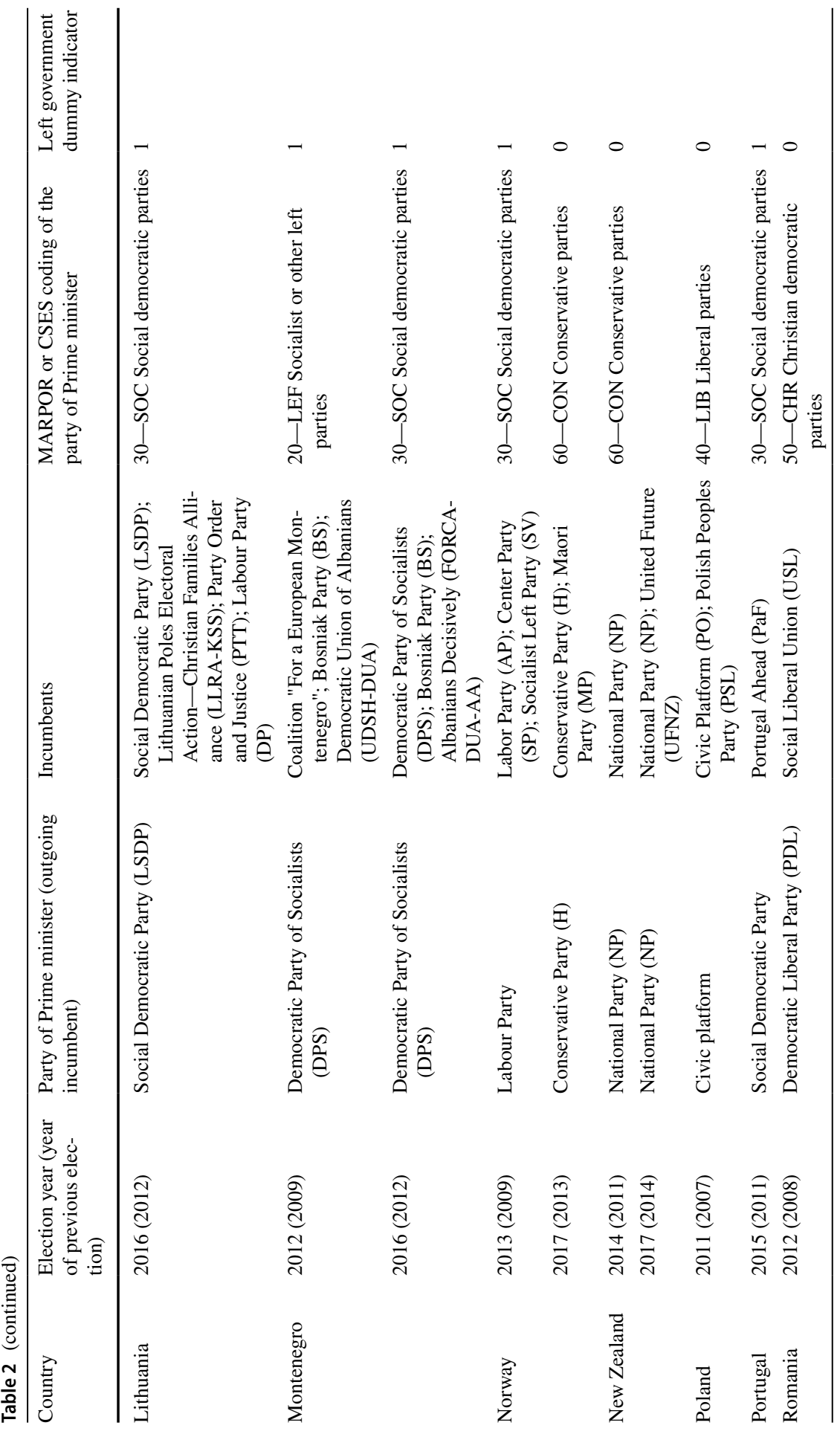




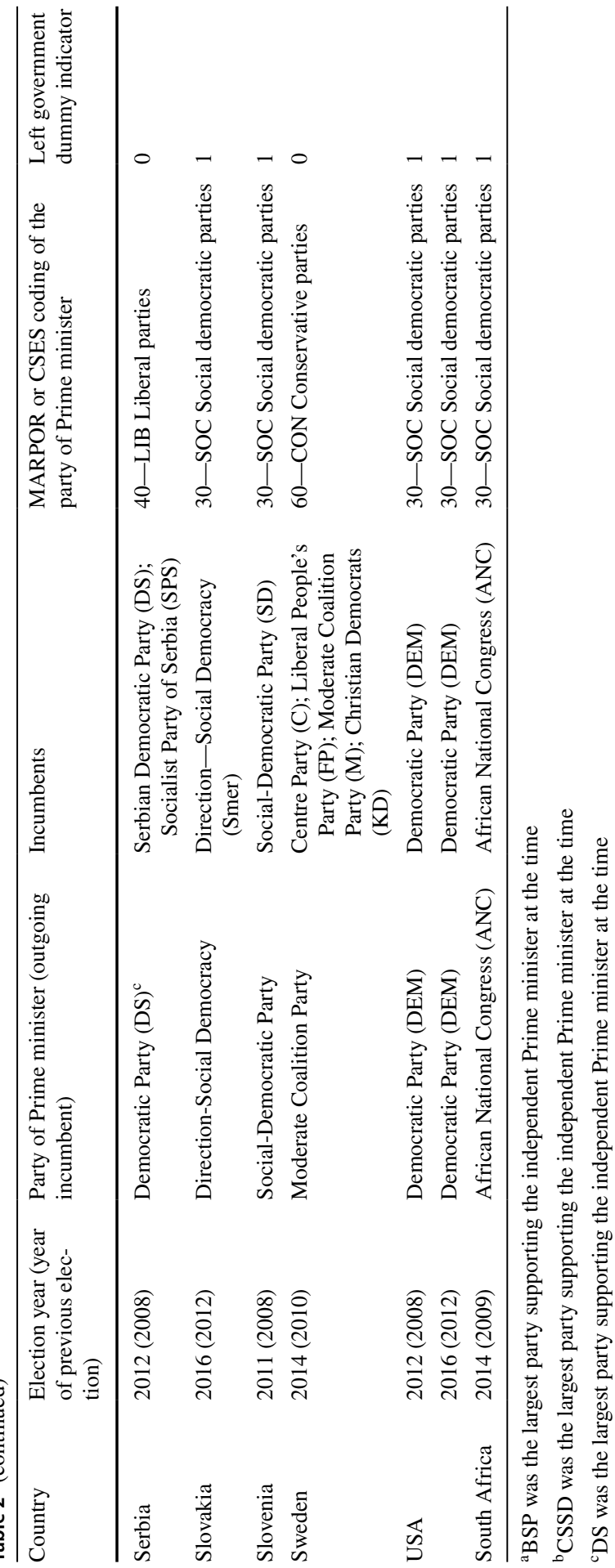

称。 


\section{Appendix 3}

See Fig. 10.

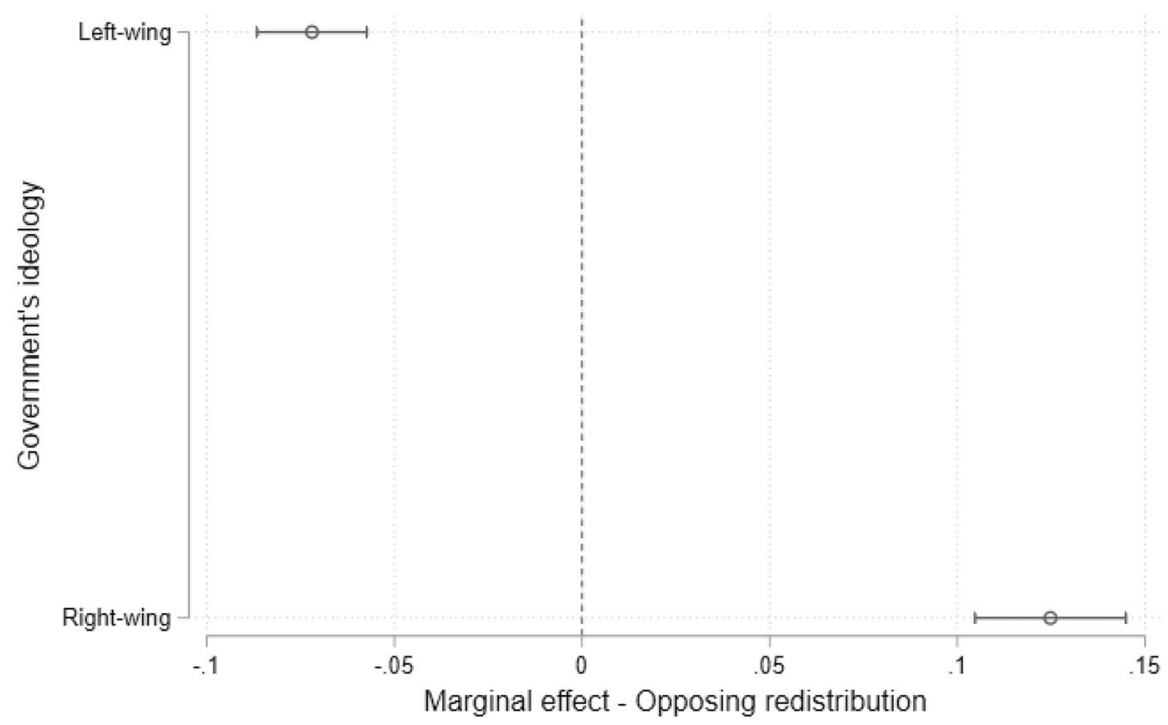

Fig. 10 Marginal effect of opposing redistribution over the government's ideology with a 95\% CI

\section{Appendix 4}

See Table 3.

Table 3 Multi-level logistic regression models_ — vote for party of Prime minister

\begin{tabular}{lllll}
\hline Vote for party of PM & Model 1 & Model 2 & Model 3 & Model 4 \\
\hline Redistribution preferences & $-0.241^{*}$ & 0.438 & $-0.948^{* * *}$ & -0.890 \\
State of economy & $(0.049)$ & $(0.391)$ & $(0.169)$ & $(0.457)$ \\
& $1.680^{* * *}$ & $1.682^{* * *}$ & $1.669 * * *$ & $1.668^{* * *}$ \\
Party ID & $(0.0620)$ & $(0.0620)$ & $(0.0621)$ & $(0.0621)$ \\
& $2.164 * * *$ & $2.164 * * *$ & $2.167 * * *$ & $2.167 * * *$ \\
Ideology & $(0.0318)$ & $(0.0318)$ & $(0.0318)$ & $(0.0318)$ \\
& $1.705^{* * *}$ & $1.704 * * *$ & $1.703 * * *$ & $1.702 * * *$ \\
Income & $(0.0596)$ & $(0.0596)$ & $(0.0596)$ & $(0.0596)$ \\
& $0.202 * * *$ & $0.203 * * *$ & $0.201 * * *$ & $0.202^{* * *}$ \\
Union membership & $(0.0423)$ & $(0.0423)$ & $(0.0423)$ & $(0.0423)$ \\
& 0.0742 & $0.0752^{*}$ & 0.0707 & 0.0706 \\
& $(0.0381)$ & $(0.0381)$ & $(0.0381)$ & $(0.0381)$ \\
\hline
\end{tabular}


Table 3 (continued)

\begin{tabular}{|c|c|c|c|c|}
\hline Vote for party of PM & Model 1 & Model 2 & Model 3 & Model 4 \\
\hline Male & $\begin{array}{l}-0.165 * * * \\
(0.0267)\end{array}$ & $\begin{array}{l}-0.165^{* * *} \\
(0.0267)\end{array}$ & $\begin{array}{l}-0.164 * * * \\
(0.0267)\end{array}$ & $\begin{array}{l}-0.164 * * * \\
(0.0267)\end{array}$ \\
\hline Age & $\begin{array}{l}-0.00818^{* * *} \\
(0.000830)\end{array}$ & $\begin{array}{l}-0.00818^{* * *} \\
(0.000830)\end{array}$ & $\begin{array}{l}-0.00820 * * * \\
(0.000829)\end{array}$ & $\begin{array}{l}-0.00820 * * * \\
(0.000829)\end{array}$ \\
\hline Education & $\begin{array}{l}0.0187 \\
(0.0437)\end{array}$ & $\begin{array}{l}0.0152 \\
(0.0436)\end{array}$ & $\begin{array}{l}0.0204 \\
(0.0437)\end{array}$ & $\begin{array}{l}0.0206 \\
(0.0437)\end{array}$ \\
\hline$\Delta$ Gini & $\begin{array}{l}-1.233 \\
(0.884)\end{array}$ & $\begin{array}{l}-0.406 \\
(0.775)\end{array}$ & $\begin{array}{l}0.427 \\
(0.838)\end{array}$ & $\begin{array}{l}0.527 \\
(0.801)\end{array}$ \\
\hline Left government & $\begin{array}{l}-0.190 \\
(0.287)\end{array}$ & $\begin{array}{l}-0.193 \\
(0.197)\end{array}$ & $\begin{array}{l}-0.877 * * \\
(0.308)\end{array}$ & $\begin{array}{l}-0.893^{* * *} \\
(0.299)\end{array}$ \\
\hline GDP growth & $\begin{array}{l}-0.133 \\
(0.398)\end{array}$ & $\begin{array}{l}-0.442 \\
(0.357)\end{array}$ & $\begin{array}{l}-0.0474 \\
(0.862)\end{array}$ & $\begin{array}{l}0.0791 \\
(0.760)\end{array}$ \\
\hline$\Delta$ Unemployment & $\begin{array}{l}0.731 \\
(0.519)\end{array}$ & $\begin{array}{l}0.638 \\
(0.487)\end{array}$ & $\begin{array}{l}0.0287 \\
(0.694)\end{array}$ & $\begin{array}{l}-0.144 \\
(0.526)\end{array}$ \\
\hline Redistribution $\times \Delta$ Gini & & $\begin{array}{l}-1.273^{*} \\
(0.105)\end{array}$ & & $\begin{array}{l}-0.115 \\
(0.743)\end{array}$ \\
\hline Redistribution $\times$ Left gov & & & $\begin{array}{l}1.419 * * * \\
(0.269)\end{array}$ & $\begin{array}{l}1.435^{* * * *} \\
(0.282)\end{array}$ \\
\hline Constant & $\begin{array}{l}-2.672 * * * \\
(0.658)\end{array}$ & $\begin{array}{l}-2.946^{* * * *} \\
(0.491)\end{array}$ & $\begin{array}{l}-2.897 * * * \\
(0.630)\end{array}$ & $\begin{array}{l}-2.942^{* * * *} \\
(0.596)\end{array}$ \\
\hline \multicolumn{5}{|l|}{ Random effects and slopes } \\
\hline Redistribution preferences & $\begin{array}{l}1.224 * * * \\
(0.240)\end{array}$ & $\begin{array}{l}1.130 \text { *** } \\
(0.216)\end{array}$ & $\begin{array}{l}0.750 * * * \\
(0.210)\end{array}$ & $\begin{array}{l}0.803^{* * * *} \\
(0.216)\end{array}$ \\
\hline Election Study & $\begin{array}{l}1.338 * * * \\
(0.271)\end{array}$ & $\begin{array}{l}1.232 * * * \\
(0.244)\end{array}$ & $\begin{array}{l}1.009 * * * \\
(0.245)\end{array}$ & $\begin{array}{l}0.953 \text { *** } \\
(0.217)\end{array}$ \\
\hline$A I C$ & $36,276.8$ & $36,255.5$ & $36,278.6$ & $36,271.4$ \\
\hline$B I C$ & $36,415.7$ & $36,403.0$ & $36,426.1$ & $36,427.6$ \\
\hline 11 & $-18,122.4$ & $-18,110.8$ & $-18,122.3$ & $-18,117.7$ \\
\hline M \& Z-Pseudo R2 & 0.4678 & 0.4682 & 0.4668 & 0.4669 \\
\hline Observations & 43,401 & 43,401 & 43,401 & 43,401 \\
\hline Number of election studies & 42 & 42 & 42 & 42 \\
\hline
\end{tabular}

Standard errors in parentheses; $* p<0.05, * * p<0.01, * * * p<0.001$

Source: CSES Module 4 (2018) \& CSES Module 5 (2020)

\section{Appendix 5}

See Table 4. 
Table 4 Multi-level logistic regression models_-vote for outgoing incumbents and MARPOR rile scale used as predictor

\begin{tabular}{|c|c|c|c|c|}
\hline Vote for incumbents & Model 1 & Model 2 & Model 3 & Model 4 \\
\hline Redistribution preferences & $\begin{array}{l}-0.694^{* * *} \\
(0.203)\end{array}$ & $\begin{array}{l}0.100 \\
(0.685)\end{array}$ & $\begin{array}{l}-0.808^{* * *} \\
(0.204)\end{array}$ & $\begin{array}{l}-0.0578 \\
(0.626)\end{array}$ \\
\hline State of economy & $\begin{array}{l}1.662 * * * \\
(0.0727)\end{array}$ & $\begin{array}{l}1.662 * * * \\
(0.0729)\end{array}$ & $\begin{array}{l}1.664 * * * \\
(0.0729)\end{array}$ & $\begin{array}{l}1.663 * * * \\
(0.0729)\end{array}$ \\
\hline Party ID & $\begin{array}{l}3.327 * * * \\
(0.0490)\end{array}$ & $\begin{array}{l}3.326^{* * * *} \\
(0.0490)\end{array}$ & $\begin{array}{l}3.326 * * * \\
(0.0490)\end{array}$ & $\begin{array}{l}3.326^{* * * *} \\
(0.0490)\end{array}$ \\
\hline Ideology & $\begin{array}{l}0.915 * * * \\
(0.0686)\end{array}$ & $\begin{array}{l}0.915^{* * *} \\
(0.0686)\end{array}$ & $\begin{array}{l}0.910 * * * \\
(0.0687)\end{array}$ & $\begin{array}{l}0.910 * * * \\
(0.0687)\end{array}$ \\
\hline Income & $\begin{array}{l}0.0951 \\
(0.0492)\end{array}$ & $\begin{array}{l}0.0949 \\
(0.0492)\end{array}$ & $\begin{array}{l}0.0956 \\
(0.0492)\end{array}$ & $\begin{array}{l}0.0951 \\
(0.0492)\end{array}$ \\
\hline Union membership & $\begin{array}{l}-0.0721 \\
(0.0424)\end{array}$ & $\begin{array}{l}-0.0725 \\
(0.0424)\end{array}$ & $\begin{array}{l}-0.0731 \\
(0.0424)\end{array}$ & $\begin{array}{l}-0.0730 \\
(0.0423)\end{array}$ \\
\hline Male & $\begin{array}{l}-0.219^{* * *} \\
(0.0311)\end{array}$ & $\begin{array}{l}-0.219 * * * \\
(0.0311)\end{array}$ & $\begin{array}{l}-0.219 \text { *** } \\
(0.0311)\end{array}$ & $\begin{array}{l}-0.219 * * * \\
(0.0311)\end{array}$ \\
\hline Age & $\begin{array}{l}-0.00610^{* * *} \\
(0.000971)\end{array}$ & $\begin{array}{l}-0.00610 * * * \\
(0.000971)\end{array}$ & $\begin{array}{l}-0.00609 * * * \\
(0.000971)\end{array}$ & $\begin{array}{l}-0.00608 * * * \\
(0.000971)\end{array}$ \\
\hline Education & $\begin{array}{l}-0.153 * * \\
(0.0501)\end{array}$ & $\begin{array}{l}-0.155^{* *} \\
(0.0501)\end{array}$ & $\begin{array}{l}-0.153^{* *} \\
(0.0501)\end{array}$ & $\begin{array}{l}-0.154 * * \\
(0.0501)\end{array}$ \\
\hline$\Delta$ Gini & $\begin{array}{l}0.877 \\
(0.720)\end{array}$ & $\begin{array}{l}1.103 \\
(1.051)\end{array}$ & $\begin{array}{l}0.539 \\
(0.729)\end{array}$ & $\begin{array}{l}1.479 \\
(0.917)\end{array}$ \\
\hline MARPOR RILE scale & $\begin{array}{l}0.00723 \\
(0.00824)\end{array}$ & $\begin{array}{l}0.0105 \\
(0.0114)\end{array}$ & $\begin{array}{l}0.0186 \\
(0.00999)\end{array}$ & $\begin{array}{l}0.0145 \\
(0.0105)\end{array}$ \\
\hline GDP growth & $\begin{array}{l}0.397 \\
(0.808)\end{array}$ & $\begin{array}{l}0.0273 \\
(0.774)\end{array}$ & $\begin{array}{l}0.698 \\
(1.079)\end{array}$ & $\begin{array}{l}0.736 \\
(0.516)\end{array}$ \\
\hline$\Delta$ Unemployment & $\begin{array}{l}-0.229 \\
(0.807)\end{array}$ & $\begin{array}{l}-0.460 \\
(0.836)\end{array}$ & $\begin{array}{l}-0.589 \\
(0.798)\end{array}$ & $\begin{array}{l}-0.546 \\
(0.748)\end{array}$ \\
\hline Redistribution $\times \Delta$ Gini & & $\begin{array}{l}-1.396 \\
(1.156)\end{array}$ & & $\begin{array}{l}-1.375 \\
(1.074)\end{array}$ \\
\hline Redistribution $\times$ RILE & & & $\begin{array}{l}-0.0248^{*} \\
(0.0119)\end{array}$ & $\begin{array}{l}-0.0303 * * \\
(0.0116)\end{array}$ \\
\hline Constant & $\begin{array}{l}-2.224 * * * \\
(0.426)\end{array}$ & $\begin{array}{l}-1.978^{*} \\
(0.777)\end{array}$ & $\begin{array}{l}-1.878 * * \\
(0.645)\end{array}$ & $\begin{array}{l}-2.388 * * * \\
(0.628)\end{array}$ \\
\hline \multicolumn{5}{|l|}{ Random effects and slopes } \\
\hline Redistribution preferences & $\begin{array}{l}1.939 * * * \\
(0.420)\end{array}$ & $\begin{array}{l}1.855^{* * *} \\
(0.429)\end{array}$ & $\begin{array}{l}1.772 * * * \\
(0.398)\end{array}$ & $\begin{array}{l}1.721^{* * *} \\
(0.390)\end{array}$ \\
\hline Election Study & $\begin{array}{l}1.382 * * * \\
(0.308)\end{array}$ & $\begin{array}{l}1.332 * * * \\
(0.311)\end{array}$ & $\begin{array}{l}1.280 * * * \\
(0.293)\end{array}$ & $\begin{array}{l}1.255^{* * * *} \\
(0.284)\end{array}$ \\
\hline$A I C$ & $26,592.7$ & $26,602.4$ & $26,599.1$ & $26,589.7$ \\
\hline$B I C$ & $26,725.9$ & $26,743.9$ & $26,740.5$ & $26,739.4$ \\
\hline $\mathrm{Ll}$ & $-13,280.4$ & $-13,284.2$ & $-13,282.5$ & $-13,276.8$ \\
\hline M \& Z-Pseudo R2 & 0.5515 & 0.5513 & 0.5501 & 0.5504 \\
\hline
\end{tabular}


Table 4 (continued)

\begin{tabular}{lllll}
\hline Vote for incumbents & Model 1 & Model 2 & Model 3 & Model 4 \\
\hline Observations & 30,338 & 30,338 & 30,338 & 30,338 \\
Number of election studies & 36 & 36 & 36 & 36 \\
\hline
\end{tabular}

Please note that higher values on MARPOR rile scale mean that party is more right. Additionally, ideology variable for models presented in Appendix 5 has been created from left-right self-placement which is first multiplied by -1 (then +1 added) if the MARPOR rile scale value is smaller than 0 (Nadeau et al. 2013)

Standard errors in parentheses; Source: CSES Module 4 (2018) \& CSES Module 5 AR2 (2020); * $p<0.05, * * p<0.01, * * * p<0.001$

Acknowledgements Invaluable support in the process of writing this article was provided by: Stephen Quinlan, Kai Arzheimer, Mary Stegmaier, Olivera Komar, Alexia Katsanidou, E. Keith Smith, Michael Lewis-Beck and Laura Stephenson, to all of whom I owe big thank you! Three anonymous reviewers provided comments which significantly improved the article, and I thank them for that Previous versions of this paper were presented at the 5th Leuven-Montreal Winter School on Elections 2018; the 76th Annual Midwest Political Science Association (MPSA) Conference 2018; the GESIS Politics PhD Lab; and the Political Science Brown-bag Research Seminar at the University of Mainz. On all these occasions, the feedback I received helped me improve the article, for which I am very grateful to all participants. As usual, any and all mistakes are my own.

Funding Open Access funding enabled and organized by Projekt DEAL.

\section{Declaration}

Conflict of interest I have no competing interests to declare. This research did not receive any specific grant from funding agencies in the public, commercial or not-for-profit sectors.

Open Access This article is licensed under a Creative Commons Attribution 4.0 International License, which permits use, sharing, adaptation, distribution and reproduction in any medium or format, as long as you give appropriate credit to the original author(s) and the source, provide a link to the Creative Commons licence, and indicate if changes were made. The images or other third party material in this article are included in the article's Creative Commons licence, unless indicated otherwise in a credit line to the material. If material is not included in the article's Creative Commons licence and your intended use is not permitted by statutory regulation or exceeds the permitted use, you will need to obtain permission directly from the copyright holder. To view a copy of this licence, visit http://creativecommons.org/licen ses/by/4.0/.

\section{References}

Alt, J., and T. Iversen. 2017. Inequality, Labor Market Segmentation, and Preferences for Redistribution. American Journal of Political Science 61(1): 21-36. https://doi.org/10.1111/ajps.12264.

Alvaredo, F., L. Chancel, T. Piketty, E. Saez, and G. Zucman. 2017. Global Inequality Dynamics: New Findings from WID. American Economic Review 107(5): 404-409.

Anderson, C.J. 2007. The End of Economic Voting? Contingency Dilemmas and the Limits of Democratic Accountability. Annual Review of Political Science 10(1): 271-296. https://doi.org/10.1146/ annurev.polisci.10.050806.155344.

Anderson, C.J., A. Blais, S. Bowler, T. Donovan, and O. Listhaug. 2005. Loser's Consent_Elections and Democratic Legitimacy. Oxford: Oxford University Press. 
Bailey, J. 2019. The Fact Remains: Party ID Moderates How Voters Respond to Economic Change. Electoral Studies 61: 102071. https://doi.org/10.1016/j.electstud.2019.102071.

Blomqvist, P., and C. Green-Pedersen. 2004. Defeat at Home? Issue-Ownership and Social Democratic Support in Scandinavia. Government and Opposition 39(4): 587-613. https://doi.org/10.1111/j. 1477-7053.2004.00137.x.

Borck, R. 2007. Voting, Inequality and Redistribution. Journal of Economic Surveys 21(1): 90-109. https://doi.org/10.1111/j.1467-6419.2007.00265.x.

Brambor, T., W.R. Clark, and M. Golder. 2006. Understanding Interaction Models: Improving Empirical Analyses. Political Analysis 14(1): 63-82. https://doi.org/10.1093/pan/mpi014.

Campbell, A., P.E. Converse, W.E. Miller, and D.E. Stokes. 1960. The American Voter. New York: Wiley.

Clarke, H., J. Reifler, T.J. Scotto, M.C. Stewart, and P. Whiteley. 2015. Valence Politics and Voting in the 2012 U.S. Presidential Election. Electoral Studies 40: 462-470. https://doi.org/10.1016/j.electstud. 2014.09.011.

Clarke, H., D. Sanders, M. Stewart, and P. Whiteley. 2011. Valence Politics and Electoral Choice in Britain, 2010. Journal of Elections, Public Opinion and Parties 21(2): 237-253. https://doi.org/10. 1080/17457289.2011.562614.

Costa Lobo, M. 2013. Dimensions of the Economic Vote: Valence, Positional and Patrimony Voting in Portugal's 2011 Elections. Electoral Studies 32(3): 460-464. https://doi.org/10.1016/j.electstud. 2013.05.021.

Curini, L., and P. Martelli. 2015. A Case of Valence Competition in Elections: Parties' Emphasis on Corruption in Electoral Manifestos. Party Politics 21(5): 686-698. https://doi.org/10.1177/1354068813 491540.

Dassonneville, R., and M.S. Lewis-Beck. 2013. Economic Policy Voting and Incumbency: Unemployment in Western Europe. Political Science Research and Methods 1(1): 53-66. https://doi.org/10. 1017/psrm.2013.9.

Dassonneville, R., \& Lewis-Beck, M. S. (2020). Inequality and Party Support: Positional Economic Voting or a New Dimension of Valence? Regional Studies.

De Sio, L., and T. Weber. 2014. Issue Yield: A Model of Party Strategy in Multidimensional Space. American Political Science Review 108(4): 870-885.

Downs, A. 1957. An Economic Theory of Political Action in a Democracy. Journal of Political Economy 65(2): 135-150. https://doi.org/10.1086/257897.

Duch, R.M., and R.T. Stevenson. 2008. The Economic Vote: How Political and Economic Institutions Condition Election Results (1 edition). Cambridge: Cambridge University Press.

Evans, G., and R. Andersen. 2006. The Political Conditioning of Economic Perceptions. The Journal of Politics 68(1): 194-207. https://doi.org/10.1111/j.1468-2508.2006.00380.x.

Ferland, B., and R. Dassonneville. 2019. Shifting Parties, Rational Switchers: Are Voters Responding to Ideological Shifts by Political Parties? Party Politics. https://doi.org/10.1177/1354068819 829207.

Fiorina, M. 1981. Retrospective Voting in American National Elections. New Haven: Yale University Press.

Fraile, M., and M.S. Lewis-Beck. 2013. Multi-dimensional Economic Voting in Spain: The 2008 Election. Electoral Studies 32(3): 465-469. https://doi.org/10.1016/j.electstud.2013.05.027.

Franklin, M.N., and C. Wlezien. 1997. The Responsive Public: Issue Salience, Policy Change, and Preferences for European Unification. Journal of Theoretical Politics 9(3): 347-363. https://doi.org/10. $1177 / 0951692897009003005$.

Ganzeboom, Harry B.G. 2015. International Social Survey Programme: Social Inequality IV - ISSP 2009 (Netherlands). GESIS Data Archive, Cologne. ZA5995 Data file Version 1.0.0. https://doi.org/10. $4232 / 1.12338$.

Green, J. 2007. When Voters and Parties Agree: Valence Issues and Party Competition. Political Studies 55(3): 629-655. https://doi.org/10.1111/j.1467-9248.2007.00671.x.

Heisig, J.P., and M. Schaeffer. 2019. Why You Should Always Include a Random Slope for the LowerLevel Variable Involved in a Cross-Level Interaction. European Sociological Review 35(2): 258279. https://doi.org/10.1093/esr/jcy053.

Hellwig, T. 2012. Constructing Accountability: Party Position Taking and Economic Voting. Comparative Political Studies 45(1): 91-118. https://doi.org/10.1177/0010414011422516.

Hellwig, T., and I. McAllister. 2019. Party Positions, Asset Ownership, and Economic Voting. Political Studies. https://doi.org/10.1177/0032321718815781. 
ISSP Research Group. 2019. International Social Survey Programme: Social Networks and Social Resources - ISSP 2017. GESIS Data Archive, Cologne. ZA6980 Data file Version 2.0.0. https://doi. org/10.4232/1.13322.

Iversen, T. (2011). Capitalism and Democracy. In The Oxford Handbook of Political Science. https://doi. org/10.1093/oxfordhb/9780199604456.013.0040

Lax, J.R., and J.H. Phillips. 2009. Gay Rights in the States: Public Opinion and Policy Responsiveness. American Political Science Review 103(3): 367-386. https://doi.org/10.1017/S0003055409990050.

León, S. 2011. Who is Responsible for What? Clarity of Responsibilities in Multilevel States: The Case of Spain. European Journal of Political Research 50 (1): 80-109. https://doi.org/10.1111/j.14756765.2010.01921.x.

Lewis-Beck, M. S. (1988). Economics and Elections: The Major Western Democracies. University of Michigan Press.

Lewis-Beck, M. S., \& Costa Lobo, M. (2017). The Economic Vote: Ordinary vs. Extraordinary Times. In The SAGE Handbook of Electoral Behaviour (p. 26). SAGE.

Lewis-Beck, M.S., and R. Nadeau. 2009. Obama and the Economy in 2008. PS Political Science and Politics 42(3): 479-483. https://doi.org/10.1017/S1049096509090775.

Lewis-Beck, M.S., and R. Nadeau. 2011. Economic Voting Theory: Testing New Dimensions. Electoral Studies 30(2): 288-294. https://doi.org/10.1016/j.electstud.2010.09.001.

Lewis-Beck, M.S., R. Nadeau, and M. Foucault. 2013. The Compleat Economic Voter: New Theory and British Evidence. British Journal of Political Science 43(02): 241-261. https://doi.org/10.1017/ S0007123412000440.

Lewis-Beck, M.S., and S. Quinlan. 2019. The Hillary Hypotheses. Perspectives on Politics 17(3): 646665. https://doi.org/10.1017/S153759271800347X.

Lewis-Beck, M.S., and M. Stegmaier. 2000. Economic Determinants of Electoral Outcomes. Annual Review of Political Science 3(1): 183-219. https://doi.org/10.1146/annurev.polisci.3.1.183.

Lewis-Beck, M.S., and M. Stegmaier. 2007. Economic Models of Voting. The Oxford Handbook of Political Behavior. https://doi.org/10.1093/oxfordhb/9780199270125.003.0027.

Lewis-Beck, M. S., \& Stegmaier, M. (2018). Economic voting. In The Oxford Handbook of Public Choice (Vol. 1, pp. 247-265). Oxford.

Lind, J. T. (2005). Why is there so Little Redistribution? Nordic Journal of Political Economy.

Magalhães, P.C. 2012. After the Bailout: Responsibility, Policy, and Valence in the Portuguese Legislative Election of June 2011. South European Society and Politics 17(2): 309-327. https://doi.org/10. 1080/13608746.2012.701410.

McCarty, N., \& Pontusson, H. J. (2011). The Political Economy of Inequality and Redistribution, pp. 665-692.

Meltzer, A.H., and S.F. Richard. 1981. A Rational Theory of the Size of Government. Journal of Political Economy 89(5): 914-927. https://doi.org/10.1086/261013.

Milanovic, B. 2012. Global Inequality Recalculated and Updated: The Effect of New PPP Estimates on Global Inequality and 2005 estimates. The Journal of Economic Inequality 10(1): 1-18. https://doi. org/10.1007/s10888-010-9155-y.

Milanovic, B., and J.E. Roemer. 2016. Interaction of Global and National Income Inequalities. Journal of Globalization and Development 7(1): 109-115. https://doi.org/10.1515/jgd-2016-0023.

Nadeau, R., Foucault, M., \& Lewis-Beck, M. S. (2009). Patrimonial Economic Voting: A Neglected Dimension. French Politics, 2(9).

Nadeau, R., M.S. Lewis-Beck, and É. Bélanger. 2013. Economics and Elections Revisited. Comparative Political Studies 46(5): 551-573. https://doi.org/10.1177/0010414012463877.

Nezi, R., and A. Katsanidou. 2014. From Valence to Position: Economic Voting in Extraordinary Conditions. Acta Politica 49(4): 413-430. https://doi.org/10.1057/ap.2014.14.

Okolikj, M., and S. Quinlan. 2016. Context Matters: Economic Voting in the 2009 and 2014 European Parliament Elections. Politics and Governance 4(1): 145-166. https://doi.org/10.17645/pag.v4i1. 458.

Paparo, A., \& Lewis-Beck, M. S. (2017). Valence and Positional Economic Voting: A Comparison Across Major Democracies. 34.

Piketty, T., and E. Saez. 2014. Inequality in the Long Run I Science. Science 344(9186): 838-843.

Pontusson, J., and D. Rueda. 2010. The Politics of Inequality: Voter Mobilization and Left Parties in Advanced Industrial States. Comparative Political Studies 43(6): 675-705. https://doi.org/10.1177/ 0010414009358672. 
Powell, G.B., and G.D. Whitten. 1993. A Cross-National Analysis of Economic Voting: Taking Account of the Political Context. American Journal of Political Science 37(2): 391-414. https://doi.org/10. $2307 / 2111378$.

Quinlan, S., \& Okolikj, M. (2018, August 30). Exploring the Neglected Dimension of the Economic Vote: A Cross-National Analysis of the Positional Economics Thesis. In The 2018 Annual Meeting of the American Political Science Association (APSA), Boston, USA.

Quinlan, S., \& Okolikj, M. (2019). Patrimonial Economic Voting: A Cross-National Analysis of Asset Ownership and the Vote. Journal of Elections, Public Opinion and Parties.

Rabinowitz, G., and S.E. Macdonald. 1989. A Directional Theory of Issue Voting. American Political Science Review 83(1): 93-121. https://doi.org/10.2307/1956436.

Rehm, P., J.S. Hacker, and M. Schlesinger. 2012. Insecure Alliances: Risk, Inequality, and Support for the Welfare State. American Political Science Review 106(2): 386-406. https://doi.org/10.1017/S0003 055412000147.

Rueda, D., \& Stegmueller, D. (2015). Preferences that Matter: Inequality, Redistribution and Voting.

Rueda, D., and D. Stegmueller. 2016. The Externalities of Inequality: Fear of Crime and Preferences for Redistribution in Western Europe. American Journal of Political Science 60(2): 472-489. https:// doi.org/10.1111/ajps.12212.

Scheve, K., and D. Stasavage. 2017. Wealth Inequality and Democracy. Annual Review of Political Science 20(1): 451-468. https://doi.org/10.1146/annurev-polisci-061014-101840.

Stiers, D., J.-F. Daoust, and A. Blais. 2018. What Makes People Believe that their Party Won the Election? Electoral Studies 55: 21-29. https://doi.org/10.1016/j.electstud.2018.07.002.

Stiglitz, J. (2012). The Price of Inequality. Norton \& Company. https://www.amazon.de/Price-InequalityJoseph-Stiglitz/dp/0393088693

Stokes, D.E. 1963. Spatial Models of Party Competition. American Political Science Review 57(2): 368377. https://doi.org/10.2307/1952828.

Stubager, R., M.S. Lewis-Beck, and R. Nadeau. 2013. Reaching for Profit in the Welfare State: Patrimonial Economic Voting in Denmark. Electoral Studies 32(3): 438-444. https://doi.org/10.1016/j.elect stud.2013.05.009.

Talving, L. 2017. The Electoral Consequences of Austerity: Economic Policy Voting in Europe in Times of Crisis. West European Politics 40 (3): 560-583. https://doi.org/10.1080/01402382.2016.1271600.

The Comparative Study Of Electoral Systems. (2018). CSES Module 4 Full Release [Data set]. CSESComparative Study of Electoral Systems. https://doi.org/10.7804/cses.module4.2018-05-29

The Comparative Study of Electoral Systems. (2020). CSES Module 5: Second Advance Release. CSESComparative Study of Electoral Systems.https://doi.org/10.7804/csesmodule5.2020-05-14

Tillman, E.R. 2008. Economic Judgments, Party Choice, and Voter Abstention in Cross-National Perspective. Comparative Political Studies 41(9): 1290-1309. https://doi.org/10.1177/0010414007 308539.

Uslaner, E.M., and M. Brown. 2005. Inequality, Trust, and Civic Engagement. American Politics Research 33(6): 868-894. https://doi.org/10.1177/1532673X04271903.

Williams, R. 2012. Using the Margins Command to Estimate and Interpret Adjusted Predictions and Marginal Effects. The Stata Journal 12(2): 308-331.

Publisher's Note Springer Nature remains neutral with regard to jurisdictional claims in published maps and institutional affiliations.

Slaven Živković is Data Processing Specialist with the Comparative Study of Electoral Systems (CSES) project at GESIS Cologne, and also a Ph. D. candidate in political science at the Johannes Gutenberg University of Mainz. Slaven is also a fellow of the Montenegrin National Election Study (MNES) project. His research interests include voting behavior, elections, public opinion and quantitative methods. 